\title{
Designing an English for Special Purposes (ESP) Course: The Case of Medical Students
}

\author{
DATONDJI Coovi Innocent \\ The Advanced Teacher Training College, the University of Abomey-Calavi, the Republic of Benin
}

\begin{abstract}
This paper is an extract from a syllabus I have conceived and designed to be used by the medical students of the Faculty of Medicine of Porto-Novo, in the Republic of Benin. My objective in writing it is to show student teachers of English as a foreign language some of the aspects and stages that have to be considered when designing a syllabus of this kind, that is, English for Special Purposes. This course is intended for all years' medical students at the Special Faculty of Medicine at Porto-Novo, in the Republic of Benin, and in any other university, who do not speak English as their mother tongue, but who need to know this language to further their studies abroad for specialization purposes when they finish their schooling in their various countries. Composed of three integrated modules, its purpose is to bring those students to satisfy their language and communication needs. It emphasizes critical thinking and favors the acquisition of the language through the natural route of development as it is learnt by native speakers. This course is grounded on a functional/notional syllabus based on what students need and want to know.
\end{abstract}

Index Terms-language development, medical students, to build communication, authentic language, language practice

\section{THE COURSE IDENTIFICATION AND LAYOUT}

The name of the Faculty should appear here.

ACADEMIC YEAR (to be defined by the lecturer)

Example: FACULTY OF MEDICINE OF PORTO-NOVO (Republic of Benin)

Subject/Field of study: English for Special Purposes

Course: English for medicine.

\begin{tabular}{|l|l|l|l|l|}
\hline Study year & Hours & Period & Day/Time & Place \\
\hline $\begin{array}{l}\text { All years' medical } \\
\text { students at the Faculty of } \\
\text { Medicine of Porto-Novo. }\end{array}$ & $\begin{array}{l}\text { Varying from 4 hours to } \\
\text { more per week, depending on } \\
\text { the study year. }\end{array}$ & $\begin{array}{l}\text { Beginning (Example: } \\
\text { November 2014.) }\end{array}$ & $\begin{array}{l}\text { Varying according to } \\
\text { the study year }\end{array}$ & $\begin{array}{l}\text { Faculty of Medicine of } \\
\text { Porto-Novo }\end{array}$ \\
\hline
\end{tabular}

\begin{tabular}{|l|l|}
\hline Identification (Name, rank and qualification of the lecturer in charge) & Other collaborators \\
\hline Example: Dr. DATONDJI Coovi Innocent, Docteur d'Etat en Linguistique et Didactique de la langue & Not applicable \\
anglaise, Advanced Practical Certificate in Teacher Training and Inspecting for TESOL, Maître de & \\
Conférences des Universités du CAMES, Retired Fulbright Professor. & \\
\hline
\end{tabular}

\section{INTRODUCTION TO THE COURSE}

\section{A. General Objective of the Course}

Considering the place of the English language in the world today, the first and general objective of this course is to familiarize the medical students at the Faculty of Medicine of Porto-Novo with the bases of medical terms and prepare them to function in English during international workshops and conferences or simply when examining patients who are English (native) speakers.

\section{B. Specific Learning Objectives}

At the end of the session (50 hours per semester), the students are expected to be able to:

1. Communicate relatively fluently in spoken English,

2. Write papers in English for international workshops and conferences, and even attempt to write in English parts of their long papers (doctoral thesis or final dissertation),

3. Understand native speakers and respond to them in a comprehensible English,

\section{Prerequisite}

Knowledge of the principles of Teaching English as a Foreign/Second Language (TEFL/TESL) or English level of "Baccalaureate" (corresponding to seven years of English learning at secondary school).

\section{Contents}


1. Introduction: On the purpose of language.

The purpose of language is to communicate. There are mostly seven broad communicative functions of language. They are:

(1) Requesting and giving information; (2) Expressing thought processes; (3) Expressing opinions; (4) Making judgments; (5) Modifying people's behavior; (6) Expressing personal feelings; and (7) Interacting socially (with specific formats).

2. Session One: Just like a teacher, anyone wanting to become a doctor must endeavor to get and develop the following dimensions:

a) The academic dimension (Cf: L'Anglais pour tous, volumes One and Two)

b) The methodological dimension (Cf: L'Anglais pour tous, volumes One and Two)

c) The human dimension (Cf: L'Anglais pour tous, volumes One and Two)

3. Session Two: Prior aspects to be considered in undertaking the learning of a foreign/second language (Cf: L'Anglais pour tous, volumes One and Two)

a) The stages of learning. b) The components of an attitude. c) The components of language aptitude.

4. Evaluation (may vary):

4.1. of the students: The students are evaluated every semester. The evaluation is composed of two parts: a written part and an oral one. The passing conditions are specified at the beginning of the course.

4.2. of the trainer: A form will be filled in by the students at the end of each semester to assess their lecturer ${ }^{1}$.

\section{E. Note to the Attention of the Teacher and the Student}

Some people think wrongly that the learning of English for Specific Purposes (ESP) consists in learning only the technical vocabulary of the concerned field or register. I completely disagree with this way of thinking. In fact, according to me, as far as the medical field for instance is concerned, what use is it for a medical doctor to know all the medical lexical items in the world if he/she cannot use them in real communication situation? If I consider for instance the word "Cardiopathy" known by a medical doctor, he can never use it communicatively if he is not able to say to his patient (s) one of the following sentences:

1) The diagnostic shows that you are suffering from Cardiopathy.

2) Your sickness is Cardiopathy.

3) I'll write you a prescription to cure your Cardiopathy.

4) If you suffer from Cardiopathy, come to the hospital.

In other words, all the other elements of the four phrases and which are written in bold letters constitute essential elements without which the single knowing of the word "Cardiopathy" will appear just useless. Concretely speaking, it is good for the medical students to learn the medical jargon or specific register, but it is certainly more profitable and practical for them to use these to engage fruitful and comprehensive conversations with their patients for establishing diagnostics and writing lifesaving prescriptions rather than lethal ones, thus increasing the death rate in our countries, by lack of competence.

\section{THE COURSE MODULES}

I have entitled the first module: "Refresher component". The activities of this component are to be carried out for four hours on a weekly basis during the first two months of the school year ${ }^{2}$.

1. MODULE ONE: REFRESHER COMPONENT (to be carried out for four hours weekly during the first two months of the school year, that is: October and November, in the Beninese educational system)

2. MODULE TWO: SPECIAL REGISTER COMPONENT (to be implemented weekly for one hour (refresher component) coupled with one hour of Special Register study (ESP) from December to May (= six months of the school year in the Beninese educational system)

After roughly two months of refresher course, the learners move into the second module which consists in putting them into simulations of the real-life medical register. To achieve this aim, I have designed a series entitled: "At the medical consultation" and featuring either conversations or dialogues between doctors and patients and students discussing medical/health issues, or points related to the same issues. Each conversation or dialogue is followed with a pedagogic follow-up work for practice by the students, in order to help them to improve their speaking and writing skills, as in Lessons 6 below, for instance).

3. MODULE THREE: PAPER READING/WRITING-RELATED ISSUES COMPONENT (to be carried out in four hours weekly during the last month of the school year. The third component is a kind of guideline designed to help the students to:

1. Understand papers written in English,

2. write papers in English for international audience/conferences, in order to

\footnotetext{
${ }^{1}$ This is an innovation introduced by me.

${ }^{2}$ The school year is split into two "semesters" to follow the regulations of the "Licence, Master, Doctorate" (LMD) system of education now being implemented in Benin.
} 
3. Write in English their doctoral dissertation (s).

\section{Methodology}

\section{Guideline:}

(1) The course is entitled: At the medical consultation. The paper presented here is an extract which contains six lessons.

(2) The conversations or dialogues which constitute the essentials of this course have been composed by me, conceiver and writer of the syllabus, just for pedagogic purposes and needs. The reader is therefore constantly invited not to pay an excessive attention to their "professional" contents

(3) The teacher who is about to implement this syllabus is also invited, if he/she wishes to do so, to draw elements from it in order to adapt it to his own teaching needs and objectives in order to enrich his own lessons.

(4) The students practice the conversations or dialogues in turn, two or more students at a time, depending on the number of the characters involved, trying to guess or figure out the missing words. At the end of the practice, they look at the answer key to check their propositions. The answer key is displayed on a separate sheet that the teacher keeps with himself/herself during the practice by the students.

(5) For each level or module, it is recommended the teacher should follow the guideline referring to the progression of the modules which has been proposed for the school year.

\section{Lesson One}

\section{Stage One: Dialogue One}

1. Instructions: Fill in the gaps in the dialogue below with the following words: injury; matter; pain; suffer; headache; allergy; wrong; condition; treatment; hurt; ache.

1) Patient: I feel really ill.

2) Doctor: Not again! What exactly is the (1)...?

3) Patient: I don't know. I have an (2)...in my joints. I have an old leg (3)...and I can't walk properly.

4) Doctor: You've been receiving (4)...for that, haven't you?

5) Patient: Yes, doctor. But it's worse now. I'm sure I've (5)...my back too.

6) Doctor: Oh! I've dropped my pen. (Patient bends down to pick it up). Thank you. I see there is nothing (6)... with your back after all.

7) Patient: Well, I (7)...from insomnia. I hardly get any sleep at nights. I can hear my heart beating all the time. I'm sure I have a heart $\mathbf{( 8 )}$...

8) Doctor: Let me listen to it. No, it seems all right to me. Oh!

9) Patient: Are you in (9)..., doctor?

10) Doctor: Yes, I have a dreadful (10)...It must be an (11)...I get it every time I see you.

2. Answer key: (1): matter; (2): ache; (3): injury; (4): treatment; (5): hurt; (6): wrong; (7): suffer; (8): condition; (9): pain; (10): headache; (11): allergy.

\section{Lesson Two}

\section{Stage One: Dialogue Two}

1. Instructions: Fill in the gaps in the dialogue below with the following words: pregnant; off; pains; treatment; medicine; expensive; take; pulse; children; get; worse; pharmacist; instructions; prescriptions; leaflet; wombs; bowels; matter; stretch; morning; clothes; normal; vomiting.

2. A dialogue between a pregnant woman $(\mathbf{P w})$ and a Doctor:

1- Pw: Good morning, doctor.

2- Doctor: Good morning, madam. What's the (1)...?

3- Pw: I feel pains in my (2)...

4- Doctor: Have you moved your (3) ...today?

5- Pw: No, doctor.

6- Doctor: Let me see, please. Lie down on the bed.

7- Pw: (Lying down) Ok, doctor.

8- Doctor: Not like that. Take your clothes (4)... first.

9- Pw: Ok, doctor.

10- Doctor: Good. (5) ...your feet/legs. (Consulting) You are pregnant. Aren't you?

11- Pw: Yes doctor, I am.

12- Doctor: When did you become (6)...?

13- Pw: Two months ago, when I missed my period.

14- Doctor: Where exactly do you feel the (7)...?

15- Pw: (Showing) Here! 
16- Doctor: Have you been having a (8)...?

17- Pw: Not yet.

18- Doctor: Ok! Now, you can (9)...up.

19- Pw: Ok! Thank you, doctor.

20- Doctor: Put your (10) ... on and sit down here.

21- Pw: Is it good here?

22- Doctor: Fine! Let me check your (11)... and take your temperature.

23- Pw: Are they (12)...?

24- Doctor: No problem. Have you been (13)...?

25- Pw: Yes, doctor.

26- Doctor: Since when?

27- Pw: Since last week.

28- Doctor: How often?

29- Pw: Every time I eat, but especially in the (14)...

30- Doctor: Have you got other (15)...?

31- $\underline{\mathrm{Pw}}$ : No, doctor. This is my first pregnancy

32- Doctor: Ok. Let me write a (16)...for you. (Writing up the prescription) Here it is. Take it. They are tablets.

33- Pw: Thank you, doctor. How do I (17)...the tablets?

34- Doctor: The (18)... are written on the (19)...inside the box for the medicine.

35- Pw: Are they (20)...?

36- Doctor: I don't know, but the (21)...will tell you.

37- Pw: Ok, doctor. Thank you. When shall I come back?

38- Doctor: In two weeks' time.

39- Pw: What if the pains get (22)...before then?

40- Doctor: Come back anytime you have a problem.

41- Pw: Shall I have to pay the fees again?

42- Doctor: Why not? I have not spent ten years studying medicine for nothing!

43- Pw: Thank you doctor. Good bye.

44- Doctor: Good bye. Take your (23)... and keep healthy.

3. Answer key: (1) matter; (2) wombs; (3) bowels; (4) off; (5) stretch; (6) pregnant; (7) pains; (8) treatment; (9) get; (10) clothes; (11) pulse; (12) normal; (13) vomiting; (14) morning; (15) children; (16) prescriptions; (17) take; (18) instructions; (19) leaflet; (20) expensive; (21) pharmacist; (22) worse; (23) medicine.

\section{Stage Two: Additional lexical items:}

1- Gynaecologist= Gynécologue; 2- Gynaecological= Gynécologique; 3- Gynaecology= Gynécologie; 4- Pregnant woman= Femme enceinte; 5- To give birth (to a baby/babies); to deliver = Accoucher; 6- To bear a child/to bear children= Porter une grossesse; 7- Echography= Echographie; 8- Caesarean= Césarienne; 9- To make pregnant= Enceinter; 10- To abort, to carry out an abortion = Faire (un) avortement; 11- Abortion= Avortement; 12- Curettage= Curetage; 13- Protected sexual intercourse = Rapport (sexuel) protégé; 14- Miscarriage = Fausses couches.

Stage Three: Follow-up work: This follow-up work is meant for the students to practice as homework.

Instruction: Use each of the words in the additional lexical list above to make up five sentences of your own. During the next class, you will compare your answers to the ones of the student sitting next to you for correction if necessary and for comments.

\section{Lesson Three}

\section{A sample of some of the sentences that a doctor can use when examining a patient}

Procedure:

Step one: The teacher hands to the students copies of the (material =) the lines below.

Step two: He/she and the students read them aloud together at least two times to check pronunciation.

Step three: The students are given time (to be determined by the teacher) to have a reading on their own.

Step four: The follow-up work.

1) Have you paid the fees? 2) What exactly is the matter (with you)? 3) What are you suffering from? 4) Let me see. 5) Let me have a look. 6) Let me have a closer look. 7) Have you been receiving treatment? 8) What medicine have you been taking? 9) When did the pain start? 10) Have you been seeing another doctor? 11) Let me take your temperature! 12) Let me check your blood pressure! 13) Let me write a prescription for you. 14) Here it is. Take it/Have it. 15) Come back next week.

Follow-up work: The students practice these sentences in pairs: one plays the role of the doctor and the second one plays the role of the patient. They change roles until all the students have had a chance to participate actively. 


\section{Lesson Four}

\section{Stage One: Dialogue Three}

Instructions: Fill in the gaps in the dialogue below with the following words: Routine, follow-up; mean; ready; note book; pregnant; financial; whining; perfusion; hospitalize; situations; father; circling; before; everything; feel; follow; strengthen; cashier's; boxes; nurse; prepare; already; of course; at once; ago; today; hurry; take; brother; call.

The dialogue: A dialogue between a gynaecologist and a pregnant woman ( $\mathrm{Pw})$

1- Pw: Good morning, doctor.

2- Doctor: Good morning, madam. I think I've seen you (1)....

3- $\underline{\mathrm{Pw}}$ : Yes, doctor. You are right. I was here two months (2)....

4- Doctor: Yes! I remember now. You were two months (3)...then.

5- Pw: Exactly.

6- Doctor: And what can I do for you (4)...today?

7- Pw: I've come for the (5)...check-up.

8- Doctor: Where is your consultation (6)...?

9- Pw: Here it is, doctor.

10- Doctor: Have you bought and taken the tablets?

11- Pw: Yes, doctor. I have finished the two (7)...already.

12- Doctor: And how do you (8)...now?

13- Pw: I think that the baby is in a (9)...to come out and be delivered.

14- Doctor: He better stay where he is for the time being.

15- Pw: I think so too.

16- Doctor: Anyway, lie down here.

17- Pw: (Lying down) Ok, doctor.

18- Doctor: (Consulting) I think you are right. I must (10)...you. You need a (11)....

19- Pw: But I'm not ready for that now.

20- Doctor: What do you (12)... by "you are not ready"?

21- Pw: I don't have any money with me.

22- Doctor: Do you want to keep your baby or not?

23- Pw: (13)...I do want to keep it.

24- Doctor: So, shut up and (14)...your husband.

25- Pw: I don't have a husband doctor.

26- Doctor: You don't have a husband. But who is the (15)...of the baby then?

27- Pw: I don't know him yet.

28- Doctor: Yet? So what do you want me to do now?

29- Pw: You must help me doctor. (16)... and holding her belly with both hands) The baby wants to come out, doctor.

30- Doctor: Ask him to keep quiet and stay inside. Under the circumstances, as I said, you need a circling. Is there anyone to attend to you?

31- Pw: Yes, doctor. I'm with my (17)....

32- Doctor: Ok. Ask him to go and pay the fees at the (18)...desk, at the reception. (Calling a nurse) Go and (19)...a bed for this woman, please.

33- Nurse: (20)..., doctor.

34- Doctor: (Addressing the woman) (21)...her.

35- Pw: Ok, doctor. Thank you.

36- Nurse: (Addressing the woman) Sit down here, while I get things (22)....

37- Doctor: (Reflecting) here we are! We speak of free of charge and gratuitous caesarians! But then, how do we handle those unexpected (23)...? How many women lose their lives and babies every day by lack of (24)...means? It's only God who can save this country!

38- Nurse: (25)... is ready, doctor.

39- Doctor: Ok. (Addressing the woman) Let's go inside. (Some time later. After the circling) Madam, you have to stay here for three days for a (26)....

40- Pw: Three days?

41- Doctor: Yes, madam. You are very weak. You need some (27)...to (28)...your health.

42- Brother: (Back from the reception) I'm back, doctor. I have (29)...paid the fees. Here is the receipt.

43- Doctor: Hand it to the (30).... Come back after tomorrow to (31)...your sister back home. Goodbye.

44- Brother: Thank you, doctor. Good bye.

Stage Two: Answer key: (1) before; (2) ago; (3) pregnant; (4) today; (5) routine; (6) notebook; (7) boxes; (8)feel; (9) hurry; (10) hospitalize; (11) circling; (12) mean; (13) of course; (14) call; (15) father; (16) whining; (17) brother; (18) 
cashier's ; (19) prepare; (20) at once; (21) follow; (22) ready; (23) situations; (24) financial; (25) everything; (26) follow-up; (27) perfusions; (28) strengthen; (29) already; (30) nurse; (31) take

Stage Three: Pedagogic follow-up work meant for the students to practice as homework

Task one: Use each of the words in the additional lexical list above to make up five sentences on your own. During the next class, you will compare your answer to the ones of the student sitting next to you for correction if necessary and for comments.

Task two: Each student is requested to put a question based on the dialogue. (Here are some examples of the questions that the students can put)

Question One: Why is it important to teach teenagers (TA) sexual education?

Answer One: It's important to teach TA sexual education because we want them to be protected against sexually transmitted diseases and non-desired pregnancies.

Question Two: What is the role of condom and femidom?

Answer Two: Condom and femidom help to protect people against sexually transmitted diseases and non-desired pregnancies.

Question Three: Are teenagers the only people concerned with/by non-desired pregnancies?

Answer Three: It's not the teenagers only who are concerned with/by non-desired pregnancies; the grown-up people are also concerned.

Question Four: What does the doctor need to succeed in his sexual education program?

Answer Four: To succeed in his sexual education program, the doctor needs parents-children's communication.

Question Five: What are some of the consequences of a non-desired pregnancy for girls?

Answer Five: Some of the consequences of a non-desired pregnancy for girls are: desire to commit abortion, sterility, school dropout and possibly death.

Question Six: Do you think that femidom is commonly used in our societies?

Answer Six: No, I don't think that femidom is commonly used in our societies, because, as has been reported by some women, placing it in the vagina is not as easy as placing the condom.

Question Seven: What are some of the methods which can be used to avoid a non-desired pregnancy?

Answer Seven: Some of the methods which can be used to avoid a non-desired pregnancy are:

1) Protected sexual relationships; 2) Abstinence; 3) Contraception.

Question Eight: What are some of the consequences of non-protected sexual relationships?

Answer Eight: Some of the consequences of non-protected sexual relationships are:

1) Sexually transmitted infections; 2) Irresponsible pregnancies; 3) Abortion; 4) Sterility; 5- Death.

Question Nine: What is the role of the parents in the sexual education of their children?

Answer Nine: The parents have a very important role to play in the sexual education of their children, because if they don't do so, street and school education will corrupt their children.

Question Ten: At what age can parents introduce sexual education to their children?

Answer Ten: It depends on the nature and characteristics of the children, and on the method the parents use. Generally speaking, we cannot set an age limit.

Question Eleven: Why is the concept of "non-protected" a false issue?

Answer Eleven: This concept is a false issue because in normal conditions, the normal issue of sexual relationships is pregnancy.

Stage Four: A question for debate: You are a (woman) gynaecologist; your daughter gets pregnant at the age of 13. How would you handle that situation?

\section{Lesson Five}

Stage One: A dialogue between a Doctor [Dr.] and a medical student [Ms]

Instructions: Fill in the gaps in the dialogue below with the following words.

dimensions, antibiotics, fulfilled, suffering, cervix, pounded, treatment, counts, absorbent, accident, reanimation, unit, doctor, conscience, preferable, persons, previous, obsolete, circumstances, surgery, care, gaping, save, equipment, lives, several, mentioned, help, amputate, anaesthetize.

1) Ms: Good morning, Dr. An (1)... has just been reported.

2) Dr: Yes, you are right. It is an emergency situation/case.

3) $\overline{\mathrm{Ms}}$ : Why, Dr?

4) Dr: Because (2)... people have died and there are many people seriously injured too.

5) Ms: Under these (3) ..., what has to be done, Dr?

6) Dr: We need an emergency (4)... for the injured people.

7) Ms: What about the surgical (5)...?

8) Dr: It has to be up-to-date, not (6)... and non-adapted. Besides, the usual light material should be available, too. 
9) Ms: What is it composed of, Dr?

10) Dr: It is composed of compress, cotton wool/cotton, alcohol, (7)... cotton wool, mercurochrome, bandages for making tourniquet in case of serious bleeding/haemorrhage [heməridj]

11) Ms: In those situations, can we operate on victims who were (8)... from other diseases such as: haemorrhoids, uterus/womb infection, the cancer of the (9)... of the uterus/womb, the cancer of the prostate, and peritonitis?

12) Dr: It depends. But what (10)... most is for the doctor to do everything he can to (11)... the (12)... of all patients. When you finish with the emergency surgeries, you can work on (13)... diseases as the ones you've (14)...

13) Ms: Where is the operation carried out?

14) Dr: In the operation/surgery (15)..., with ultra-modern and appropriate equipment. The inappropriate and wornout equipment has to be completely thrown away if we don't want to complicate the situation of the injured people.

15) Ms: In what condition do we have to operate on the (16)...?

16) Dr: Depending on the situation, we have to (17)... them. In this case, we can practice local or general anaesthesia and do our best to avoid making (18)... wounds on them.

17) Ms: Are you saying that the light wounds are (19)..., Dr?

18) Dr: Yes of course, they are.

19) Ms: Please, Dr., what must be done after the operation?

20) Dr: After the operation, sometimes, we have to do cardio vascular or cardio-lung (20)...

21) Ms: Please, Dr. what if for instance one of the legs of the person is completely (21)... or pulverized?

22) Dr: When there is nothing else to do, we can't (22)... it. We have to (23)..., cut off the injured/damaged leg, and take measures to avoid convulsions during the surgery.

23) Ms: What has to be done when the operation is successful?

24) Dr: When all good conditions have been (24)...and the operation has been successful, we need to observe the patient and give him after surgery (25)..., consisting in medicating him/her with strong (26)...

25) Ms: I've heard that sometimes, there are conflicts between the medical staff and the patients' sires/begetters regarding the kind of (27)... to give the patients.

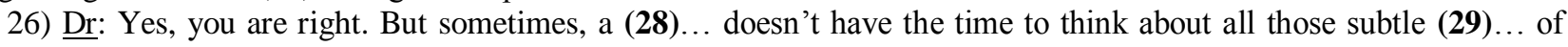
human life. He just has to do his job as his (30)... calls upon him to do.

\section{Stage Two: Answer key:}

(29) dimensions, (26) antibiotics, (24) fulfilled, (8) suffering, (9) cervix, (21) pounded, (27) treatment, (10) counts, (7) absorbent, (1) accident, (20) reanimation, (15) unit, (28) doctor, (30) conscience, (19) preferable, (16) persons, (13) previous, (6) obsolete, (3) circumstances, (4) surgery, (25) care, (18) gaping, (11) save, (5) equipment, (12) lives, (2) several, (14) mentioned, (22) help, (23) amputate, (17) anaesthetize.

Stage Three: Pedagogic follow-up work meant for the students to practice as homework

Task one: Use each of the words in the additional lexical list above to make up five sentences. During the next class, you will compare your answers to the ones of the student sitting next to you for correction if necessary and for comments.

Task two: lexical items and sentences (Exploration and follow-up questions)

Procedure:

1) Each student first reads two lexical items/sentences and then answers related questions put by his/her mates.

2) The teacher comes in for clarifications if necessary, and presents issues for debates. For instance, the teacher may ask the students to point out the difference between lexical item five (Cardiomyopathy) and lexical item six (Cardiopathy), insisting on the concepts: "intensive vocabulary" and "extensive vocabulary". As an illustration, lexical item five relates to "intensive vocabulary", whereas lexical six relates to "extensive vocabulary".

3) When they come to sentence 11 [The patient is under intensive care], the teacher can ask the following questions:

a) In what circumstances can a doctor say this sentence?

b) To who (m)?

4) When they come to sentences $\mathbf{1 5}$ and $\mathbf{1 6}$, the teacher may ask the students: "Are these sentences appropriate with good ethics"?

Stage Four: Additional activities: a debate about faked medicines

Section One: Background of the topic:

The fight against the faked medicines has known a rapid development and interest with the creation of what is called "The Chirac Foundation", after the name of one of the former Presidents of France, Mr. Jacques Chirac ${ }^{3}$. A day, October $12^{\text {th }}$, has even been retained to celebrate this fight every year. A conference on this issue was held in Cotonou, presided over by President Chirac, and the headquarters of the Foundation were set up in Cotonou (Benin).

${ }^{3}$ Information on the Radio Station: “Soleil FM”, during its programme: 'Le Boulevard des Opinions' (Tuesday, October 2015) 
Unfortunately, the headquarters moved from Cotonou to Lomé (Togo) on Monday, October $12^{\text {th }}, 2015$, after it was found out that despite the importance given to Cotonou in this fight by establishing the headquarters in Benin, it is in Benin that the fight has regressed in favor of the sale of the faked medicines which has outrageously gained tremendous momentum. Therefore, we can say that the fight has failed in Benin. This failure is clearly understandable and is easily explained by the following factors:

1) Our political leaders do not really have, so to speak, the political will to effectively fight against the faked medicines.

2) They certainly have their own financial interests in preserving and encouraging the sale of the faked medicines.

3) These medicines are publicly sold in the two biggest open markets: Dantokpa market in Cotonou and Adjégounlè market in Porto-Novo. They are managed by SOGEMA, a government-owned society in charge of managing the markets in Benin.

4) Even when the civil society invites the members of the government in charge of health to attend conferences and working sessions to discuss the issue, they do not participate.

Therefore, Dr. Moudiatou Toukourou (2015), the leader of one of the branches of the National Order of Pharmacists, has urged them "to change their attitude of "I don't care" in order to join them in the fight and attend the public manifestations and demonstrations scheduled for November to sensitize the populations". This sensitization is all the more important as the political will is missing and as the side effects of the consumption of faked medicines are numerous. A number of these side effects on the youth are listed below:

a) Their eyes are red looking, as if blood-injected, looking at people evasively.

b) They are hyper tensed. ${ }^{4}$

The youth become faked medicine-addicted because of these two factors: 1) the weakness of their purchasing power and 2) their ignorance of the side effects elicited above. There are two regrettable facts about this situation. Firstly, due to these two factors, many people prefer buying the faked medicines and indulge in the practice of using them. Secondly, even the official pharmacies do sell the faked medicines quite freely, unofficially, as it is said, supported by the government.

In Asia for instance, the medicines do not obey any formal dosage. Our frontiers are pervasive, to such extent that many medicines cannot be traced back to their true origins, thus increasing the danger in the situation. Many pharmacies are real "crematorium", in the sense that the medicines sold there are not conserved according to the rules, as they are exposed to the dust coming from the streets and to heat, without any precaution of air conditioning.

Section Two: The debate:

1) Discuss in your groups the ways and means to solve the problem of faked medicines.

2) Guideline:

a) Discuss some of the reasons for the existence of the phenomenon of faked/counterfeit medicines: i) Unemployment; ii) Poverty; iii) Ignorance; iv) Manifest dishonesty, insincerity, and unfairness of the suppliers; v) The populations are badly informed or not informed at all; vi) Lack of ethics.

b) Some people say: "If you kill the street pharmacies, then you will kill the third world". What do you think about this statement?

c) Who supplies the street sellers with the medicines?

d) There is a need to sensitize the populations on the dangers/drifts of the faked medicines.

e) The networks/channels of the faked medicines.

f) It will take time, energy and good will to overcome the plague of the counterfeit medicines.

3) Homework: You are planning to specialize in ...(write the name of the specialty: example: pediatrics) Write at least 15 lines to state your motivation and the objectives you want to reach.

\section{Lesson Six}

Stage One: A conversation (between a Male Doctor [MDr.], a Nurse [Ns], a Man Patient [Mp] and a Woman Patient [WP], in a private clinic.

Instructions: Fill in the gaps with the following lexical items.

consultation[fees]; as [well]; like [vomiting]; talk; rubbish; toilet; next; would; meet; rent; appointment; register; expensive; disturbing; specialist; cleaner; insulting; take; private; electricity; suffering; maintenance; government; wages; half; sick; imagine; wasting; lying; exploiting.

1- Man patient (Mp): Good morning, madam. I'm seriously ill.

2- Nurse: What are you ... (1) from?

3- Mp: I don't know exactly. I have a diarrhoea/diarrhea. I go to stool sololo/salala. And I'm vomiting ... (2) well.

4- $\underline{\mathrm{N}}$ : I see. This is contamination. Have you been drinking soiled water recently?

5- $\underline{\mathrm{Mp}}$ : Are you the doctor? I want to ... (3) to the doctor. Is he around/here?

\footnotetext{
${ }^{4}$ The youth buy from the women, by the sides of the streets, varieties of tablets that they call "one giga" and that the riders of motorbikes called "Zémidjans" take in coffee, tea or "sodabi" every morning before they dash off to their daily activities to give themselves some strength in order to keep awake during the whole day.
} 
6- $\mathrm{N}$ : Yes, but it is a woman.

7- $\mathrm{Mp}$ : A woman?

8- $\underline{\mathrm{N}}$ : Is this a problem for you, Sir?

9- $\underline{\mathrm{Mp}}$ : Yes, madam. I don't want to stand naked before a woman. I don't want a woman to examine my private parts.

10- N: So what do you want me to do?

11- Mp: [Holding his chest] I feel ... (4) vomiting. [Effectively vomiting]

12- N: What (5)!!! Go to the ... (6) to tidy up yourself. (Calling the ... (7). Come to clean up this place. (Addressing the other patients)

13- Who is ... (8)?

14- Woman patient: I am. Good morning, madam.

15- Ns: Good morning, madam. Can I help you?

16- WP: Yes, madam. I ... (9) like to ... (10) the doctor.

17- Ns: Do you have an ... (11) with him?

18- WP: No, madam. It's the first time I'm here.

19- Ns: Ok, let me ... (12) your name.

20- WP: Please do.

21- Ns: What's your name then?

22- WP: (Introducing herself)

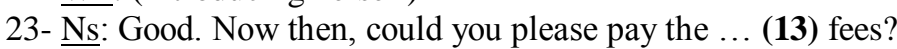

24- WP: How much are they, Madam?

25- Ns: 10.000 CFA Francs.

26- WP: Wow!!! 10.000 CFA Francs? That's too ... (14)!!!

27- Ns: The doctors who work here are all ... (15), not generalists.

28- WP: So what? You are ... (16) the people!

29- Ns: Are you a sick person or a police officer? Have you come here for consultation or for ... (17) us?

30- WP: ... (18) it as you like it.

31- Ns: Don't forget that this is a ... (19) clinic; the doctor has to pay the ... (20), the ... (21) bills to have power, the bills for water, for the ... (22) of the equipment, the various ... (23) taxes and our ... (24) at the end of every month.

32- WP: I see. I understand.

33- Ns: Do you want to pay or not?

34- WP: Can I pay ... (25) now, that is 5,000 Francs CFA and the rest later on?

35- Ns: What do you mean by: "later"?

36- WP: At the end of the treatment.

37- Ns: Do you think we can guess when the treatment will end?

38- WP: Don't ask me. You said that the doctors here are specialists.

39- Ns: So what?

40- WP: So, the treatment shouldn't take long, and besides, the doctor should know when the treatment will be over.

41- Ns: I see, but he is not God.

42- WP: This is none of my business. All I know is that you said that the doctors who work here are all specialists.

So, I shouldn't take long to pay the remaining half!

43- Ns: Are you really ... (26), madam?

44- WP: More than you can ... (27)!

45- Ns: So, pay and stop ... (28) my time.

46- WP: I'm not, madam. It's simply that the fees are too high.

47- Ns: So, why don't you go to a state-owned hospital?

48- WP: I cannot go there, madam. People say that the doctors there do not have a good reputation.

49- Ns: But most of the time, they are the same who own private clinics.

50- WP: So how do you explain that they are not efficient when they work in public hospitals?

51- Ns: Why don't you go ahead and ask them? This is pure/sheer nonsense. This is what many people say.

52- WP: And I think that to some extent, they are right, because most state-owned hospitals are considered as death places. Generally speaking, you enter them standing and upright, but you leave them ... (29). [The bell rings]

53- MDr: (Calling the nurse) Nurse!

54- Ns: Yes, doctor.

55- MDr: What is all that noise at your desk?

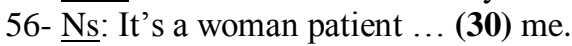

57- MDr: Let me come and see. (The doctor coming to the reception room and addressing the woman patient) Good morning, madam.

58- WP: Good morning, sir. Are you the doctor? How are you?

59- MDr: I am dazzled by your smile. As soon as I saw you, my temperature jumped and my breathing choked.

60- WP: So, I can pay half of the fees? 
61- MDr: Come with me to the consultation room. Come with me to my office, please!

Stage Two: Answer key: 1- suffering; 2-as (well); 3- talk; 4- like; 5- rubbish; 6- toilet; 7- cleaner; 8- next; 9- would; 10- meet; 11- appointment; 12- register; 13- consultation; 14- expensive; 15- specialist; 16- exploiting; 17- insulting; 18- take; 19- private; 20- rent; 21- electricity; 22- maintenance; 23- government; 24- wages; 25- half; 26- sick; 27imagine; 28- wasting; 29- lying; 30- disturbing.

Stage Three: Additional lexical items:

1- DNA = deoxyribonucleic acid (the chemical in the cells of animals and plants that carries GENETIC information and is a type of NUCLEIC ACID): a DNA test.

2- (Institute, etc. $)$ of forensic medicine $=$ medico legal. 3 - Medicinal $=$ caused by a medicine $=$ médicamenteux $($ Ex: arthrite médicamenteuse $=$ arthritis due to use of drugs. 4 - Arthrosis $=$ arthrose.5- Arteriosclerosis $=$ artériosclérose. 6 Arterial $=$ artériel. 7 - Arteritis $=$ artérite. 8 - To bloody $=$ ensanglanter, souiller (ses mains) de sang.

Stage Four: Pedagogic follow-up work

Task 1: Imagine the rest of the story.

Task 2: Each student is requested to put a question based on the conversation.

Part one: Samples of the questions put by the students on the basis of the above conversation.

Question one: Why does the first patient say that the consultation fees in this private clinic are very expensive?

Answer one: He says so because 10.000 CFA Francs are certainly beyond her financial capacities.

Question two: Why does the first patient not want to be examined by a woman doctor?

Answer two: Because he doesn't want a woman doctor to see his private parts.

Question three: How do people consider/view public hospitals?

Answer three: People consider/view public hospitals as death places.

Question four: How much does the woman who made the doctor's temperature jump want to pay for consultation fees?

Answer four: She wants to pay half of the fees in a first time, and the rest later on.

Question five: What happened to the doctor when he saw the woman patient?

Answer five: His temperature jumped and his breathing choked.

Question six: What is the level of qualification of the doctors in the conversation?

Answer six: They are both specialist.

Question seven: What has the patient done on the floor in the reception room?

Answer seven: He has vomited.

Question eight: What is the nurse's feeling after the vomiting?

Answer eight: She is disgusted.

Question nine: What is the nurse's reaction after the vomiting?

Answer nine: She calls the cleaner to clean what she calls the rubbish.

Question ten: According to the patient, are doctors efficient in public hospitals?

Answer ten: No, they are not.

Question eleven: With what money do (the) doctors pay the nurses' wages in private clinics?

Answer eleven: (The) doctors pay the nurses' wages with the consultation fees.

Question twelve: What does the nurse think that the second patient has come to do?

Answer twelve: The nurse thinks that the second patient has come to insult them in the clinic.

Question thirteen: What does the doctor say at the end of the conversation?

Answer thirteen: At the end of the conversation, the doctor says: "Come with me to my office".

Question fourteen: What does the doctor say when he sees the woman patient?

Answer fourteen: When he sees the woman patient, the doctor says: "I'm dazzled by your smile".

Question fifteen: What has probably caused the patient's diarrhea?

Answer fifteen: Spoiled or contaminated water has probably caused the patient's diarrhea.

Question sixteen: How much does the woman patient propose to pay?

Answer fifteen: The woman patient proposes to pay half of the fees.

Question seventeen: Why did the woman patient come to the private clinic?

Answer seventeen: The woman patient came to the private clinic because, as she said: "Doctors in public hospitals do not have good reputation."

Question eighteen: Why was the patient surprised to hear that the doctor was a woman?

Answer eighteen: The patient was surprised because he did not want a woman to examine his private parts.

Question nineteen: What brought the patient to the private clinic?

Answer nineteen: Diarrhea brought the patient to the private clinic.

Question twenty: Why did the nurse ask the patient if she was really sick?

Answer twenty: Because the patient said strange/bizarre things. 


\section{CONCLUSION}

In this paper I have attempted to show some of the steps that have to be followed when one wants to write a syllabus of English for Special Purposes. It has dealt with medical studies. It has highlighted how the syllabus has been implemented through listening comprehension exercises, reading comprehension exercises, dialogues, reading passages of various kinds and writing sessions in order to develop in the students a solidly grounded competence in the four language skills and in vocabulary building. In fact, all the four skills have been integrated, exploring the best elements of the following teaching methods:

- The Natural Approach, which allows students to participate and contribute according to their own levels of proficiency.

- The Structural Approach, which provides an understanding of grammar and builds skills for academic success.

- Total Physical Response, which builds listening comprehension through easy, enjoyable physical activities.

- Language Development through Content, which uses content area readings to reinforce comprehension and thinking skills and prepare students for mainstream academic/practice courses.

The language and the practice of authentic material have been developed throughout the syllabus. In writing it, I have paid attention to the fact that many teachers are not masters of the situations prevailing in their classes, who are often condemned to use textbooks which are narrow-minded in their approach, textbooks which are badly written in their progression, whose themes are boring to the students and far from their daily realities, inadequate with their language needs and interests, offering them few opportunities to practice the target language and take an active part in the lecture, textbooks which are finally little preoccupied by the academic successes of slow learners.

\section{REFERENCES}

[1] Benhamou, Emile et al. (1978). Speak English (5è). Paris: Fernand Nathan Editeur.

[2] Bouet, J. \& Shirley Bouet. (1970). L’Anglais en Afrique. 5è. Paris : Hatier.

[3] Bouet, J. \& Shirley Bouet. (1970). L’Anglais en Afrique. 4è. Paris : Hatier.

[4] Bouet, J. \& Shirley Bouet. (1970). L’Anglais en Afrique. 3è. Paris : Hatier.

[5] Carnet, Didier. (2010). Lexique Anglais/Français à l'usage des Professions Paramédicales. Paris: Ellipses Editions Marketing. S.A.

[6] Corbeil, Jean-Claude \& Ariane Archambault. (1994). The Macmillan Visual Dictionary. Canada: Macmillan, Inc.

[7] Cripwell, Kenneth et al. (1993). Go for English. London: The Macmillan Press Ltd/Edicef.

[8] Datondji, Coovi Innocent. (1997). L’Anglais pour tous. (Tomes 1 et 2). Porto-Novo : Editions Presto.

[9] Defour, François et al. (1976). English in Action, Cours d'Anglais pour les Sections Industrielles des Collèges d'Enseignement Technique, B. E. P. Première Année. Paris : Editions Fernand Nathan.

[10] Gibbs, Diana \& Noel Goodey. (1978). Imagine you're English - Book 2. Paris : Librairie Classique Eugène Belin.

[11] Gusdorf, Florent. (2008). Pratique de l'Anglais médical. Lexique à l'usage des professionnels de la santé. Paris : Ellipses Edition Marketing. S.A.

[12] Hall, Eugene J. (1985). Orientation in American English. National Textbook Company: Lincolnwood, Illinois, USA.

[13] Murphy, Fiola. (2008). Lexique médical. Paris : Ellipses Edition Marketing. S.A.

[14] Papa, Iantorno. (1989). Turning Points. Reading, Massachusetts: Addison-Wesley Publishing Company.

[15] Peterson, Pat Wilcox (ed.). (1986). ESP in Practice. Washington, D.C.: English Language Programs Division.

[16] Rouanet-Laplace, Joëlle. (2015). Les mots clés de la santé. Paris : Bréal

[17] Webster's Ninth New Collegiate Dictionary. (1983). Springfield, Massachusetts, USA: Merriam-Webster Inc.

[18] Zaffran, Barbara \& David Krulik. (1991). Everyday English (Book) 4). Lincolnwood, Illinois, USA: National Textbook Company.

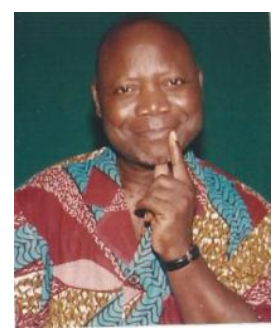

DATONDJI Coovi Innocent (a playwright and poet), born in Paouignan in Benin Republic, a French speaking country in West Africa), is an Associate Fulbright Professor of linguistics and of the didactics of English. He was formerly a teacher at and the Director of the Advanced Teacher Training College of the University of Abomey-Calavi in the Republic of Benin, a French speaking country in West Africa. His love for languages in general and for English especially has led him to write L'Anglais pour tous, in volume one and volume two, to help learners of English as a foreign/second language to have a rapid and long standing knowledge of that language.

Associate Professor (Maître de Conférences) of the Universities of the African and Malagasy Council for University Education (CAMES), Professor Innocent Coovi DATONDJI holds a "Doctorat d'Etat" in linguistics and the didactics of English. He has written and put on the stage fifteen plays. He has also written an epistolary novel: Hard Roads, published in 1996 by the Publishing House: "Les Flamboyants" at Cotonou, in the Republic of Benin in West Africa. He has studied English at the Universities of Leeds (1973, in England), of Illinois (1981, in the United States of America), of Ball State, Indiana (1984, in the United States of America), and of Iowa (1995, in the United States of America) and has obtained several diplomas in the teaching of English overseas and as a foreign or second language, and an Advanced Certificate in Inspecting teachers of English as a foreign or second language. In 1995, he attended the International Writing Program at the University of Iowa in the 
United States of America where he was awarded the title of Honorary Writing Fellow. In the academic year 2006-2007, he received an official invitation from the government of the United States of America to go and teach English at La Guardia Community College at the City University of New York as a Fulbright English Teacher. In the year 2013, he retired from civil service but he has continued his activities of consulting teacher and researcher in the field of language teaching. 